UDK 616-008

\title{
CHARACTERISTICS OF ENDOCRINE DISORDERS IN CHILDREN, LIVING IN CONDITIONS OF HIGH LEVEL RISK OF INHALATION EXPOSURE TO BENZENE, PHENOL, BENZO (A) PYRENE
}

\author{
K.P. Luzhetsky1,2, O.Yu. Ustinova1,2, O.A. Maklakova1,2, L.N. Palagina1 \\ ${ }^{1}$ FBSI "Federal Scientific Center for Medical and Preventive Health Risk Management Technologies", Russian \\ Federation, Perm, 82 Monastyrskaya St., 614045 \\ ${ }^{2}$ Perm State National Research University, Russian Federation, Perm, 15 Bukireva St., 614990
}

\begin{abstract}
The study of incidence of endocrine diseases in children, living in conditions of high level risk of inhalation exposure to chemical technogenic factors of large industrial center, has been performed. In the condition of high level risk of chronic aerogenic exposure to benzene, phenol, benzo (a) pyrene the violations of thyroid homeostasis, carbohydrate and fat metabolism (goiter (E04.9), the excess food (E67.8) and obesity (E66.0)) were diagnosed in 1.3-2.0 times more likely than in the control group. The relationship of the formation of endocrine disorders in children with increased content of benzene, phenol and benzo (a) pyrene in blood has been established. Children, living in the areas with chemical atmospheric pollution with substances influencing hormonogenesis and light iodine deficit, have a reduced level of iodine provision, changes in the structure and volume of the thyroid gland 1.7-2.4 times higher than in the control group.
\end{abstract}

Key words: children, endocrine disorders, benzene, phenol, benzo (a) pyrene.

Among the chemical technological factors contributing to the contamination of a large industrial city, the most serious threat of endocrine diseases, hormonogenesis disorders and development processes in chronic inhalation exposure comes from organic compounds (benzene, phenol, benzo(a)pyrene) in the setting of deficiency of essential trace elements (iodine, zinc) [2, 4-6].

Exposure to chemicals that negatively affect the organs of the endocrine system significantly contributes to the development of thyroid diseases, metabolic disorders and obesity, abnormalities in the physical and psychological development of children, reduction in their intellectual abilities, increased morbidity and, as a consequence, deterioration in the quality of life and health of the nation [1, 3-8].

However, earlier studies do not fully characterize the clinical features of endocrine disorders in children living in the environment of high-risk chemical inhalation exposure to man-made factors of a large industrial center.

(C) Luzhetsky K.P., Ustinova O.Yu., Maklakova O.A., Palagina L.N., 2014

Luzhetsky Konstantin Petrovich - Candidate of Medical Sciences, Head of clinic of ecodependent and industrially conditioned pathology (e-mail: nemo@fcrisk.ru; tel.: 8 (342) 236-80-98). 64).

Ustinova Olga Yurievna - MD, Professor, Deputy Director of Clinical Care (e-mail: ustinova@fcrisk.ru; ph: +7 (342) 236-32-

Maklakova Olga Anatolievna - Candidate of Medical Sciences, Head of consulting and polyclinic department (e-mail: olga_mcl@fcrisk.ru; ph:+7 (342) 237-27-92).

Palagina Larisa Nikolaevna - Pediatric thyroid specialist (e-mail: root@fcrisk.ru; ph: +7 (342) 237-25-34). 
The purpose of the study is to identify features of endocrine disorders in children living in the environment of high-risk chemical inhalation exposure to man-made factors (benzene, phenol and benzo(a)pyrene).

Materials and methods. We performed a laboratory chemical, analytical and functional examination of the children living in a large industrial city with exceeding levels of benzene, phenol and benzo(a)pyrene in the air - up to 4.1/1.35 MPC max single / MPCdaily average. The study group was made up of 190 children aged 3-7 (5.4 \pm 0.26 city), 45.8\% of the group - boys (87) and $54.2 \%$ - girls (103). All the surveyed children were divided into groups by type of hazard quotient (HQ) - airborne organic compounds (phenol, benzene, and benzo(a)pyrene): 92 children living on the border of the industrial district (HQ 0.23-0.61-0.79) - study group 1; 98 children living near the industrial center (HQ 0.24-1.7-1.45), - study group 2

The control group included 94 children aged 3-7 (5.5 \pm 0.09 years old) living in a relatively unpolluted neighborhood (HQ $0.09-0.43-0.94$ ), while $43.6 \%$ of all the surveyed children were boys (41) and 56.4\% - girls (53). The areas under study had light iodine deficiency.

To identify the characteristics of the endocrine system disorders, hormonogenesis and developmental processes in children, we carried out an in-depth clinical and laboratory examination that consisted of:

1) analysis of medical records (form 026/u-2000) and results of an in-depth examination by medical specialists (pediatrician, endocrinologist); 2) evaluation of thyroid homeostasis (TSH, T4 free, TPO antibodies in the blood) by the method of enzyme immunoassay; 3 ) determination of urinary iodine excretion in a single urine sample by the cerium arsenite method (O. Wawschi $\neg$ nek, 1985); 4) ultrasound scan of the thyroid gland (position, size, volume, visual assessment of external contours of the gland, tissue echogenicity and its echo-structure, assessment of the nature of blood supply to the gland) was performed according to the standard procedure on an expert class Toshiba VIAMO (Japan) using a linear multifrequency sensor.

The level of zinc in the blood was determined with the help of atomic spectrophotometry using PERKIN-ELMER-3110 spectrophotometer with flame atomization; benzo(a)pyrene with the help of HPLC, benzene and phenol - using capillary gas chromatography and paraphase analysis on "Chromatek-Crystal-5000." 
Hygienic assessment of the quality of the outdoor air in the areas of children's residence was conducted based on the results of field observations carried out in 2008-2012 and put together in the form of an array of one-time/average daily maximum concentrations ( $\mathrm{mg} / \mathrm{m} 3)$.

Health risk assessment was conducted in accordance with R 2.1.10.1920-04 "Guidance to Public Health Risk Assessment under Environmental Exposure".

To determine the cause-and-effect relations between the chemical technogenic compounds (phenol, benzene, benzo(a)pyrene) in the outdoor air and the development of endocrine system disorders in children characterized by clinical syndromes and functional disorders, we referred to mathematic modelling that included the analysis of probability of registration of the analyzed indicators with an increasing concentration of chemical substances in blood.

Processing of the study results was carried out with the help of parametric methods of variation statistics (f-test and t-test). To assess the differences in the values of the parameter between small samples, we used distribution-free Mann-Whitney $U$-test.

Results and Discussion. Analysis of the quality of the outdoor air based on the field studies of the content of chemicals showed violation of hygienic standards (MACone-time maximum/daily average) in all the analyzed areas. At the same time, in the outdoor air in the observation areas located in the area of industrial exposure, the level of benzo(a)pyrene, phenol and benzene by 1.35-4.1 times exceeded $(p \leq 0,05)$ the maximum allowable concentrations (MAC MACone-time maximum/daily average) (Table 1)

Table 1

Levels of chemical substances in the outdoor air of an industrial center in 2008-2012 based on the field observations, MAC one-time maximum / MAC daily average

\begin{tabular}{|l|c|c|}
\hline \multirow{2}{*}{ Substance/region } & \multicolumn{2}{|c|}{ Observation area } \\
\cline { 2 - 3 } & & 2 \\
\hline Benzene & $1.4 / 0.25$ & - \\
\hline Phenol & $4.1 / 0.67$ & $3.7 / 0.96$ \\
\hline Benzo(a)pyrene & $-/ 0.77$ & $-/ 1.35$ \\
\hline
\end{tabular}

Based on the field observation estimates and approximation of the field and calculated data on the outdoor air pollution in the areas of children's residence, we determined the presence of impermissible chronic risk of health disorders in children under exposure to benzo(a)pyrene and benzene to $1.7(H Q)$ (Table 2). 
Table 2

Health quotient values $(H Q)$ in the conditions of chronic aerogenic exposure to pollutants in the industrial areas based on the field studies / approximateion of the field data and the calculated estimates

\begin{tabular}{|l|c|c|c|}
\hline \multirow{2}{*}{ Substance/region } & \multicolumn{2}{|c|}{ Observation group } & \multirow{2}{*}{ Control group } \\
\cline { 2 - 3 } & 1 & 2 & $-/ 0.43$ \\
\hline Benzene & $0.78 / 0.61$ & $-/ 1.70$ & $-/ 0.09$ \\
\hline Phenol & $0.33 / 0.23$ & $0.50 / 0.32$ & $-/ 0.94$ \\
\hline Benzo(a)pyrene & $0.75 / 0.79$ & $1.45 / 1.45$ & \\
\hline
\end{tabular}

The influence of the analyzed substances (benzene, phenol, benzo(a)pyrene) formed the hazard indexes for the endocrine system and hormonogenesis at the level 1.7-2.38 (HI), development disorders - 2.23-4.04 (HI) (Table 3).

Table 3

Hazard index values $(H I)$ for hormonogenesis and development processes with chronic aerogenic exposure to the pollutants in the industrial areas

\begin{tabular}{|l|c|c|c|}
\hline \multirow{2}{*}{ Critical organs and systems } & \multicolumn{2}{c|}{ Observation group } & \multirow{2}{*}{ Control group } \\
\cline { 2 - 3 } & 1 & 2 & 1,36 \\
\hline Endocrine system and hormonogenesis & 1,70 & 2,38 & 1,56 \\
\hline Development process & 2,23 & 4,04 & \\
\hline
\end{tabular}

The analysis of the assessment results showed that the total hazard index (HI) for the endocrine system and the development processes in the polluted areas is on average 1.3-2.2 times higher than in the comparison areas.

In the course of the chemico-analytical studies, we determined that the average level of benzene $(0.003 \pm 0.001 \mathrm{mg} / \mathrm{dm} 3)$ in the blood of children from the observation group 2 is by 2.1 times higher as compared to the control group $(0.0014 \pm 0.0006 \mathrm{mg} / \mathrm{dm} 3)(\mathrm{p}<0.05)$. The level of phenol $(0.056 \pm 0.02-0.07 \pm 0.01 \mathrm{mg} / \mathrm{dm} 3)$ in the blood of children from groups 1,2 is by $1.5-1.8$ times higher as compared to the control group $(0.038 \pm 0.008 \mathrm{mg} / \mathrm{dm} 3)(\mathrm{p}<0.05)$, by $5.6-7.0-$ reference level $(0.01 \pm 0.037 \mathrm{mg} / \mathrm{dm} 3)(\mathrm{p}<0.05)$. The level of benzo(a)pyrene $(0.00001 \mathrm{ng} / \mathrm{dm} 3)$ in the control group is twice the reference level and by 1.6 times higher than the average group value in the control group $(0.0000061 \mathrm{ng} / \mathrm{dm} 3)(\mathrm{p}<0.05)$. The level of zinc $(3.07 \pm 0.13-$ $3.32 \pm 0.12 \mathrm{mg} / \mathrm{dm} 3)$ in the blood of children from all the analyzed groups is by 2.1-2.3 times lower than the reference level (Table 4). 
The level of chemical substances in the blood of children in the analyzed groups, $\mathbf{m g} / \mathbf{d m}^{3}, M \pm m$

\begin{tabular}{|l|c|c|c|c|}
\hline \multirow{2}{*}{ Substance } & \multirow{2}{*}{ Reference level } & \multicolumn{2}{|c|}{ Observation group } & \multirow{2}{*}{ Control group } \\
\cline { 3 - 4 } & & 1 & 2 & \\
\hline Benzene & $0,0 \pm 0,0$ & $0,0007 \pm 0,0006$ & $0,003 \pm 0,001^{*, * * *}$ & $0,0014 \pm 0,0006$ \\
\hline Phenol & $0,01 \pm 0,0037$ & $0,056 \pm 0,02^{*, * * *}$ & $0,07 \pm 0,01^{*, * *}$ & $0,038 \pm 0,008$ \\
\hline Benzo(a)pyrene & $0,0 \pm 0,0$ & 0,0000012 & $0,00001^{*, * * *}$ & 0,0000061 \\
\hline Zinc & $7,00 \pm 0,014$ & $3,07 \pm 0,128^{*, * * *}$ & $3,32 \pm 0,122^{* *}$ & $3,19 \pm 0,11$ \\
\hline
\end{tabular}

Note: ${ }^{*}$ - significance of differences with the reference level, $p_{1} \leq 0.05 ;{ }^{* *}$ - significance of difference with the control group, $p_{2} \leq 0.05$.

Endocrine pathologies in the overall structure of the revealed diseases in the observation groups took the 5 th place in terms of frequency and were diagnosed 2.0 times more frequently (36.2\%) as compared to the control group $(18.0 \%, \mathrm{p}=0.03)$. The highest level of endocrine pathology was determined in observation group $2-36.2 \%(\mathrm{p}=0.02)$.

Priority nosologies in the observation groups included the following: Hypothyrosis (E04.9), hypernutrition (E67.8) and obesity (E66.0) in 7.3-10.1\%, 6.4-10.9\% and 1.0-3.0\% of patients, which is 1,3-2,0 higher as compared to the control group $(\mathrm{p} \leq 0,05)$ (Table 5).

Children residing in areas with unfavorable sanitary and hygienic situation showed a significant cause-and-effect relation between the probability of endocrine system diseases, hyper nutrition and elevated level of benzene in blood $(\mathrm{R} 2=0.76 ; \mathrm{p}=0.00)$ and benzo(a)pyrene $(\mathrm{R} 2=0.31-0.64 ; \mathrm{p}=0.00)$ (Table 6).

Table 5

Endocrine system diseases in children in the analyzed areas, \%

\begin{tabular}{|l|c|c|c|c|c|}
\hline \multirow{2}{*}{ Nosology } & \multicolumn{2}{|c|}{ Observation group } & Control & \multicolumn{2}{c|}{ Significance of idfference } \\
\cline { 6 - 6 } \cline { 5 - 6 } & 1 & 2 & group & $p_{1}$ & $p_{2}$ \\
\hline Hypothyrosis (E04.9) & 7,3 & 10,1 & 5,8 & 0,74 & 0,03 \\
\hline Hypernutrition (E67.8) & 6,4 & 10,9 & 6,1 & 0,81 & 0,04 \\
\hline Subnutrition (E44.1) & 5,2 & 6,1 & 2,0 & 0,03 & 0,02 \\
\hline Obesity (E66.0) & 1,0 & 3,0 & 0,0 & 0,49 & 0,03 \\
\hline Higher height (E34.4) & 3,1 & 5,1 & 3,1 & 0,67 & 0,05 \\
\hline Lower height (E34.3) & 2,1 & 1,0 & 1,0 & 0,49 & 0,49 \\
\hline Total & 25,1 & 36,2 & 18,0 & 0,17 & 0,02 \\
\hline
\end{tabular}

N o te: $p_{1}-$ significance of difference of the observation group 1 with the control group; $p_{2}-$ significance of difference of the observation group 2 with the control group.

Table 6

Parameters of the relationship model between nosologies and disease classes of the endocryne system in children residing in the analyzed areas under chemical exposure

\begin{tabular}{|l|c|c|c|c|c|}
\hline \multicolumn{1}{|c|}{ Model parameters } & $b_{0}$ & $b_{1}$ & $R^{2}$ & $F$ & $p$ \\
\hline Benzene - endocrine system diseases & $-2,759$ & 342,4 & 0,766 & 344,87 & 0,00 \\
\hline Benzo(a)pyrene - endocrine system diseases & $-1,877$ & 655,7 & 0,312 & 132,91 & 0,00 \\
\hline Benzo(a)pyrene - abundant nutrition (E67.8) & 2,644 & 133,1 & 0,637 & 509,66 & 0,00 \\
\hline
\end{tabular}


The level of the pituitary-thyreoid hormones (PTH - 1,2 $\pm 0,2-1.8 \pm 0.1 \mathrm{mcIU} / \mathrm{cm} 3$ and free T4- 16,4 $\pm 1,1-16,6 \pm 0,5 \mathrm{pmol} / \mathrm{l})$, antibodies to thyrioid peroxidase $(1.9 \pm 0.5-3.0 \pm 3.6 \mathrm{IU} / \mathrm{cm} 3)$ in children was within the standard values, while the level of free thryroxine in observation groups was by 1.2 times significantly lower than such in the control group $-18.6 \pm 0.5 \mathrm{pmol} / 1(\mathrm{p} \leq 0.05)$. Observation group 1 showed an insufficient level of iodine supply $(8.47 \pm 2.2 \mu \mathrm{g} / 100 \mathrm{~cm} 3)$, iodine excretion with urine was 1.5 times lower as compared to the control group $(12.4 \pm 3.5 \mu \mathrm{g}$ $/ 100 \mathrm{~cm} 3)$, and 1,2 lower as compared to the physiological norm. when assessing the level of iodine deficit, reduced level of iodine in urine was revealed in $75.0-90.0 \%$ of patients as compared to $44.4 \%$ in the control group ( $p=0.016-0.027$ ) (Table 7).

We established significant cause-and-effect relations between the probability of iodine reduction in urine and higher level of phenol in blood ( $\mathrm{R} 2=0.14-0.39, \mathrm{~F}=12.01-45.53$; $\mathrm{p}=0.000-0.002)$.

Ultrasound studies of the thyroid gland revealed changes in the structure and volume of the organ in 32.6-43.4\% in children in the observation group, diffuse change in the structure of the thyroid - in 28.7-36.7\% which is 1.7-2.4 times higher than in the control group (16.7$17.9 \%, \mathrm{p}=0.00-0.079$ ) (Table 8).

Table 7

Results of the studies of hormonal homeostasis and thyroperoxidase antibodies $(M \pm m)$

\begin{tabular}{|l|c|c|c|c|c|}
\hline \multirow{2}{*}{ Parameter } & \multicolumn{2}{|c|}{ Norm } & \multicolumn{2}{c|}{ Observation group } & \multirow{2}{*}{ Control group } \\
\cline { 2 - 5 } & Low & High & 1 & 2 & \\
\hline T4 free, $\mathrm{pmol} / \mathrm{l}$ & 10,0 & 25,0 & $16,6 \pm 0,5^{*}$ & $16,4 \pm 1,1^{*}$ & $18,6 \pm 0,5$ \\
\hline PTH, mcIU/cm3 & 0,3 & 4,0 & $1,4 \pm 0,1$ & $1,2 \pm 0,2^{*}$ & $1,6 \pm 0,1$ \\
\hline TP antibodies, IU/cm ${ }^{3}$ & 0,0 & 30,0 & $1,9 \pm 0,5$ & $3,0 \pm 3,6$ & $2,9 \pm 1,0$ \\
\hline Iodine in urine, $\mu \mathrm{g} / 100 \mathrm{~cm}^{3}$ & 10,0 & 50,0 & $8,47 \pm 2,2^{*}$ & $10,6 \pm 2,7$ & $12,4 \pm 3,5$ \\
\hline
\end{tabular}

N o t e : ${ }^{*}$ - significance of difference of the indicators with the control group $(p \leq 0.001-0.05)$.

Table 8

Results of the thyroid ultrasound studies in children residing in the analyzed areas, \%

\begin{tabular}{|l|c|c|c|c|c|}
\hline \multirow{2}{*}{ Nosology } & \multicolumn{2}{|c|}{ Observation group } & \multirow{2}{*}{ Control group } & \multicolumn{2}{c|}{ Significance of difference } \\
\cline { 2 - 5 } & 1 & 2 & $p_{1}$ & $p_{2}$ \\
\hline Increased (border) thyroid volume & 27,6 & 33,4 & 21,8 & 0,347 & 0,09 \\
\hline $\begin{array}{l}\text { Presence of changes in the structure and } \\
\text { volume of the gland }\end{array}$ & 32,6 & 43,4 & 16,7 & 0,012 & 0,00 \\
\hline Diffuse changes of the structure & 28,7 & 36,7 & 17,9 & 0,079 & 0,004 \\
\hline Normal structure & 59,4 & 56,6 & 80,3 & 0,00 & 0,00 \\
\hline
\end{tabular}

Note: $p_{1}$ - significance of differences of the observation group 1 with the control group; $p_{2}-$ significance of difference of the observation group 2 with the control group .

Conclusions. According to the results of the study, in children living in the areas of highrisk chronic aerogenic exposure to benzene, phenol and benzo (a) pyrene, endocrine pathology 
was diagnosed 2.0 times more frequently $(36.2 \%)$ than in the control group $(18.0 \%, \mathrm{p}=0.02)$. We established a significant cause-and-effect relation between the endocrine system disorders and excess food with high content of benzene in blood $(\mathrm{R} 2=0.76 ; \mathrm{p}=0.00)$ and benzo(a)pyrene $(\mathrm{R} 2=0.31-0.64 ; \mathrm{p}=0.00)$.

We diagnosed a reduced level of iodine and microelement (zinc) (1.5-times lower urinary iodine excretion compared to the control group - 8,5mkg / $100 \mathrm{~cm} 3$, the level of free thyroxine in the observation group was significantly 1.2 times lower than that in the control group, the zinc content in blood was 2.1-2.3 times lower compared the reference level) associated with exposure to chemical goitriferous agents (reduction in iodine excretion with increasing content of phenol in the blood, $\mathrm{R} 2=0.14-0.39, \mathrm{~F}=12.01-45.53, \mathrm{p}=0.000-0.002$ ).

Ultrasound examination of the thyroid gland in the observation group showed changes in the structure and volume of the organ in $27.6-43.4 \%$ of the patients that is by $1.6-2.0$ times higher than in the control group $(16.7-21.8 \% \mathrm{p}=0.01-0.05) .28 .7 \%$ children with high phenol content in blood (up to 1.5 times higher) (observation group 1) were diagnosed as having changes in the structure and volume of the thyroid gland. In the observation group 2 (the benzene levels was 2.1 times higher, phenol - 1.8 times higher, benzo(a)pyrene - 1.6 times higher) revealed changes in the structure and volume of the thyroid gland in $43.4 \%$ of children, with diffuse changes - in $36.7 \%$ of children.

Thus, in the course of the survey it was proved that non-carcinogenic risk of chronic diseases of the endocrine system in children in the conditions of air pollution with benzene, phenol and benzo(a)pyrene takes the form of increased endemic goitre (E04.9), redundant nutrition (E67.8), and obesity (E66.0).

\section{References}

1. Baranov A.A., Il'in A.G. Osnovnye tendencii dinamiki sostojanija zdorov'ja detej v rossijskoj federacii. puti reshenija problem [Key trends in the health of children in the Russian Federation. Solutions to the problems]. Vestnik Rossijskoj akademii medicinskih nauk, 2011, no. 6, pp. $12-18$.

2. Vozgoment O.V., Korjukina I.P., Aminova A.I., Luzheckij K.P., Farnosova S.V. Gigienicheskaja harakteristika faktorov, formirujushhih tireoidnuju patologiju u detej [Hygienic characteristics of the factors forming the thyroid pathology in children]. Fundamental'nye issledovanija, 2010, no. 2, pp. 28-30.

3. Dedov I.I., Mel'nichenko G.A., Troshina E.A. Deficit joda - ugroza zdorov'ju i razvitiju detej v Rossii. (Nacional'ny doklad) [Iodine deficiency - a threat to the health and development of children in Russia. (National report)]. Moscow, 2006. 123 p.

4. Zajceva N.V., Zemljanova M.A., Kirjanov D.A. Vyjavlenie osobennostej formirovanija joddeficitnyh sostojanij u detej $\mathrm{v}$ uslovijah vozdejstvija jekologicheskih faktorov maloj intensivnosti (na primere Permskoj oblasti) [Identifying the features of formation of iodine 
deficiency states in children under the impact of environmental factors of low intensity (on the example of the Perm region)]. Vestnik Rossijskoj akademii medicinskih nauk, 2001, no. 6, pp. 39.

5. Zajceva N.V., Maj I.V., Balashov S.Ju. Mediko-biologicheskie pokazateli sostojanija zdorov'ja naselenija $\mathrm{v}$ uslovijah kompleksnogo prirodno-tehnogennogo zagrjaznenija sredy obitanija [Biomedical public health indicators in the conditions of integrated natural and manmade environmental pollution]. Izvestija Samarskogo nauchnogo centra Rossijskoj akademii nauk, 2009, vol. 11, no. 1-6, pp. 1144-1148.

6. Luzheckij K.P., Ustinova O.Ju., Palagina L.N. Strukturno-dinamicheskij analiz jendokrinnoj patologii $\mathrm{u}$ detej, prozhivajushhih $\mathrm{v}$ uslovijah vozdejstvija himicheskih tehnogennyh faktorov sredy obitanija (na primere Permskogo kraja) [Structural and dynamic analysis of endocrine diseases in children living in the conditions of chemical man-made environmental factors (on the example of the Perm Krai)]. Zdorov'e naselenija i sreda obitanija, 2013, no. 11 (248), pp. 32-35.

7. Luzheckij K.P. Joddeficitnye zabolevanija prirodno-obuslovlennogo proishozhdenija u detej Permskogo kraja [Iodine deficiency diseases of natural origin in children of the Perm Krai]. Zdorov'e naselenija i sreda obitanija: ezhemesjachnyj informacionnyj bjulleten', Moscow, 2010, no. 3, pp. 25-30.

8. Luzheckij K.P., Korjukina I.P., Ustitnova O.Ju., Burdina L.V., Shtina I.E. Osobennosti kliniko-laboratornogo statusa $\mathrm{u}$ detej $\mathrm{s}$ joddeficitnymi zabolevanijami, prozhivajushhih $\mathrm{v}$ uslovijah kombinirovannogo vozdejstvija prirodno-tehnogennyh faktorov [Peculiarities of clinical and laboratory status in children with iodine deficiency diseases, living in the combined effects of natural and man-made factors]. Fundamental'nye issledovanija, 2010, no. 2, pp. 65-67. 